Nucl, Instr, \& Methoo in

Phys. Res.

SAND98-2883J

\title{
EFFECTS OF HYDROGEN IMPLANTATION INTO GaN
}

\author{
S.J. Pearton ${ }^{(1)}$, C.R. Abernathy ${ }^{(1)}$, R.G. Wilson ${ }^{(2)}$, J.M. Zavada ${ }^{(3)}$, C.Y. Song ${ }^{(4)}$, M.G.

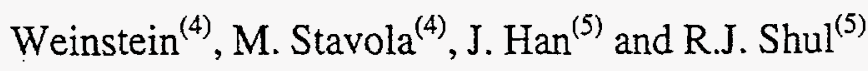

${ }^{(1)}$ Department of Materials Science and Engineering

University of Florida, Gainesville, FL 32611 USA

${ }^{(2)}$ Consultant, Stevenson Ranch, CA 91381 USA

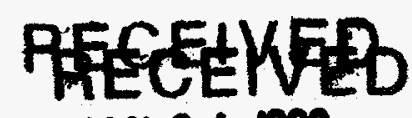

JAM $21 \mathrm{RSB}$

${ }^{(3)}$ US Army Research Office, Research Triangle Park, NC 27709 USA

छछł।

${ }^{(4)}$ Department of Physics

Lehigh University, Bethlehem, PA 18015 USA

${ }^{(5)}$ Sandia National Laboratories, Albuquerque, NM 87185 USA

\section{ABSTRACT}

Proton implantation in $\mathrm{GaN}$ is found to reduce the free carrier density through two mechanisms - first, by creating electron and hole traps at around $E_{C}-0.8 e V$ and $E_{V}+0.9 e V$ that lead to compensation in both $\mathrm{n}$ - and p-type material, and second, by leading to formation of $(\mathrm{AH})^{\circ}$ complexes, where $\mathrm{A}$ is any acceptor $(\mathrm{Mg}, \mathrm{Ca}, \mathrm{Zn}, \mathrm{Be}, \mathrm{Cd})$. The former mechanism is useful in creating high resistivity regions for device isolation, whereas the latter produces unintentional acceptor passivation that is detrimental to device performance. The strong affinity of hydrogen for acceptors leads to markedly different redistribution behavior for implanted $\mathrm{H}^{+}$in $\mathrm{n}$ - and $\mathrm{p}-\mathrm{GaN}$ due to the chemical reaction to form neutral complexes in the latter. The acceptors may be reactivated by simple annealing at $\geq 600^{\circ} \mathrm{C}$, or by electron injection at $25-150^{\circ} \mathrm{C}$ that 


\section{DISCLAIMER}

This report was prepared as an account of work sponsored by an agency of the United States Government. Neither the United States Government nor any agency thereof, nor any of their employees, make any warranty, express or implied, or assumes any legal liability or responsibility for the accuracy, completeness, or usefulness of any information, apparatus, product, or process disclosed, or represents that its use would not infringe privately owned rights. Reference herein to any specific commercial product, process, or service by trade name, trademark, manufacturer, or otherwise does not necessarily constitute or imply its endorsement, recommendation, or favoring by the United States Government or any agency thereof. The views and opinions of authors expressed herein do not necessarily state or reflect those of the United States Government or any agency thereof. 


\section{DISCLAIMER}

Portions of this document may be illegible in electronic image products. Images are produced from the best available original document. 
produces debonding of the $(\mathrm{AH})^{\circ}$ centers. Implanted hydrogen is also strongly attracted to regions of strain in heterostructure samples during annealing, leading to pile-up at epi-epi and epi-substrate interfaces. IR spectroscopy shows that implanted hydrogen also decorates $\mathrm{V}_{\mathrm{Ga}}$ defects in undoped and n-GaN.

Corresponding Author: S.J. Pearton

Dept. Mat. Sci., Eng., 132 Rhines Hall

P.O. Box 116400

University of Florida, Gainesville, FL 32611 USA

Phone: 352/846-1086

Fax: $352 / 846-1182$

Email: spear@mse.ufl.edu 
PACS Codes:

Keywords:
68.55L, 72.80E, 71.55E

hydrogen, GaN, compensation, device isolation, defects 


\section{INTRODUCTION}

Atomic hydrogen plays an important role in the defect chemistry of GaN [1-25]. Most epitaxial GaN is grown by Metal Organic Chemical Vapor Deposition (MOCVD) according to the reaction $[1,2]$

$$
\left(\mathrm{CH}_{3}\right)_{3} \mathrm{Ga}+\mathrm{NH}_{3} \rightarrow \mathrm{GaN}+\mathrm{CH}_{4}+\mathrm{H}_{2}
$$

and thus there is a large hydrogen flux available, part of which remains in the layer after cooldown. The strong affinity for atomic hydrogen to pait with acceptor dopants such as $\mathrm{Mg}$ leads to the experimental fact that as-grown $\mathrm{GaN}(\mathrm{Mg})$ is generally highly resistive, and the acceptors must be reactivated using thermal annealing at $\geq 700^{\circ} \mathrm{C}$ under $\mathrm{N}_{2}$ [1], or minority carrier injection at $\geq 25^{\circ} \mathrm{C}[2,3]$. However if the sample is then re-exposed to a hydrogen flux, it can revert to a highly resistive state. In some cases, such as low pressure MOCVD, or Molecular Beam Epitaxy (MBE), the hydrogen flux is lower or non-existent, and $\mathrm{GaN}(\mathrm{Mg})$ grown by these methods can show p-type conductivity as-grown. The $\mathrm{Mg}-\mathrm{H}$ complexes can be detected by local vibrational-mode spectroscopy [26]. At this point donor dopant complexes with hydrogen have not been detected, but there is some evidence from secondary ion mass spectrometry (SIMS) that donor-hydrogen pairing does occur.

It is also clear that hydrogen can enter $\mathrm{GaN}$ during many different process steps, including wet and dry etching, plasma enhanced chemical vapor deposition of dielectrics and boiling in water $[13,17]$. The entry of hydrogen has been confirmed both by the effect on the electrical properties of the near-surface region (i.e. dopant passivation) and by SIMS on deuterated samples. In this paper we report some of the effects of direct ${ }^{1} \mathrm{H}^{+}$or ${ }^{2} \mathrm{H}^{+}$implantation into $\mathrm{GaN}$. 


\section{EXPERIMENTAL}

Samples of GaN 1-3um thick (undoped, Si-doped or Mg-doped) were grown on c-plane $\mathrm{Al}_{2} \mathrm{O}_{3}$ by either MOCVD at $1040^{\circ} \mathrm{C}$, or Metal Organic Molecular Beam Epitaxy (MOMBE) at $900^{\circ} \mathrm{C}$. Protons $\left({ }^{1} \mathrm{H}^{+}\right)$or deuterons $\left({ }^{2} \mathrm{H}^{+}\right)$were implanted at either a single energy (typically 40 $\mathrm{keV}$ ) and dose (typically $\left.5 \times 10^{15} \mathrm{~cm}^{-2}\right)$, or with a multiple energy (25-300 keV), multiple dose $\left(6 \times 10^{14}-1 \times 10^{15} \mathrm{~cm}^{2}\right)$ scheme designed to create a nearly uniform hydrogen profile at, a concentration of $-5.6 \times 10^{19} \mathrm{~cm}^{-3}$ to a depth of $2.1 \mu \mathrm{m}$. Subsequent annealing was performed under flowing $\mathrm{N}_{2}$ at temperatures of $300-1100^{\circ} \mathrm{C}$.

\section{RESULTS AND DISCUSSION}

\section{(a) Thermal stability}

We found that implanting ${ }^{1} \mathrm{H}^{+}$or ${ }^{2} \mathrm{H}^{+}$ions into both $\mathrm{n}$ - and p-type GaN produced a strong increase in sheet resistance of the material. For doses above $\sim 10^{15} \mathrm{~cm}^{-2}$, it was possible to $\Omega$

- increase the sheet resistance from the $10^{3} / \square$ range to $>10^{10} \Omega / \square$. This is similar to the case of proton implantation into GaAs and other III-V compound semiconductors, where the energetic ion bombardment creates deep levels within the gap, which act as traps for carriers [9]. This is the basis for implant isolation schemes in these materials. From the temperature dependence of the resistivity of the implanted $\mathrm{GaN}$, we determined that proton implantation creates levels at around $\mathrm{E}_{\mathrm{C}}-0.8 \mathrm{eV}$ in $\mathrm{n}-\mathrm{GaN}$ and $\mathrm{E}_{\mathrm{V}}+0.9 \mathrm{eV}$ in $\mathrm{p}-\mathrm{GaN}$. Thus, in both conductivity types, the Fermi level will move deeper into the gap as a result of implantation, and the material resistivity will increase. However the damage created by ${ }^{1} \mathrm{H}^{+}$or ${ }^{2} \mathrm{H}^{+}$implantation is not particularly thermally stable, and annealing at $\sim 400^{\circ} \mathrm{C}$ restores the material to its original conductivity. These results are in basic agreement with the data of Binari et.al. [22]. 
In ${ }^{2} \mathrm{H}^{+}$implanted, undoped $\mathrm{GaN}$, there is little loss of deuterium from the material until $\geq 700^{\circ} \mathrm{C}$ (Figure 1). By $900^{\circ} \mathrm{C}, \sim 80 \%$ of the deuterium is lost by evolution from the surface. This is a similar thermal stability to that of deuterium incorporated in the bulk of $\mathrm{GaN}$ from plasma exposure (labeled "bulk" in Figure 1), suggesting similar microscopic sites for the deuterium. However in the case of plasma exposure there is also a high-concentration $\left(>10^{20} \mathrm{~cm}^{-3}\right)$, nearsurface $(<0.1 \mu \mathrm{m})$ region in the deuterium profile. As shown in Figure 1, this near-surface deuterium is lost from the GaN over a broad range of temperatures, which suggests a variety of different lattice locations for the deuterium.

There are clear differences in the redistribution behavior between $\mathrm{n}$ - and p-type GaN implanted with ${ }^{2} \mathrm{H}^{+}$ions. Figure 2 shows SIMS profiles of ${ }^{2} \mathrm{H}$ in n-type (left) or p-type (right) $\mathrm{GaN}$, as a function of post-implant annealing temperature. Due to the strong tendency for formation of $\mathrm{Mg}-\mathrm{H}$ complexes, a plateau begins to form in the p-type material by $500^{\circ} \mathrm{C}$, and there is strong accumulation at the heterointerface (at $\sim 1 \mu \mathrm{m}$ depth).

\section{(b) Vibrational Spectroscopy}

Figure 3 shows an infra-red spectrum from an undoped GaN sample implanted with the multiple-energy ${ }^{1} \mathrm{H}^{+}$scheme and annealed at $400^{\circ} \mathrm{C}$. These bands shift to frequencies $\sim 1.35$ times lower when ${ }^{2} \mathrm{H}^{+}$is implanted, confirming the presence of hydrogen in the centers responsible for the IR bands [15]. All of these bands anneal out by $\sim 650^{\circ} \mathrm{C}$, and $\sim 10 \%$ of the implanted hydrogen was IR-active. The observed frequencies are close to those predicted by Van de Walle [16] for $\mathrm{V}_{\mathrm{Ga}}-\mathrm{H}$ complexes (those for $\mathrm{V}_{\mathrm{N}-\mathrm{H}} \mathrm{H}$ are predicted to be near $600 \mathrm{~cm}^{-1}$ ), indicating that we are observing the stretching vibrations of $\mathrm{N}-\mathrm{H}$ bonds. At this stage we are unable to determine the number of $\mathrm{H}$ atoms involved in each of the complexes, due to broad nature of the bands. 


\section{SUMMARY AND CONCLUSIONS}

Implantation of hydrogen into $\mathrm{GaN}$ leads to a number of different defect species, including $\mathrm{V}_{\mathrm{Ga}}-\mathrm{H}$ complexes and $\mathrm{Mg}-\mathrm{H}$ centers that are $\mathbb{R}$-active and electrically active trap states

around $\mathrm{E}_{\mathrm{C}}-0.8 \mathrm{eV}$ (in n-type) and $\mathrm{E}_{\mathrm{V}}+0.8 \mathrm{eV}$ (in p-type) that increase sample resistance. The thermal stability of the implanted hydrogen is the highest we have observed in any compound semiconductor.

\section{ACKNOWLEDGMENTS}

The work at University of Florida is partially supported by NSF grant No. DMR-9732865 and a DARPAJEPRI grant (E.R. Brown/J. Melcher). The work of R.G. Wilson is partially supported by ARO, and that at Lehigh University was supported by ONR grant no. N00014-941-0117. Sandia is a multiprogram laboratory operated by Sandia Corporation, a LockheedMartin company, for DOE under grant no. DE-AC04-94AL85000. 


\section{REFERENCES}

[1] S. Nakamura, N. Iwasa, M. Senoh and T Mukai, Jap. J. Appl. Phys. $\underline{31} 1258$ (1992).

[2] H. Amano, M. Kito, K. Hiramtes and I. Akasaki, Jap. J. Appl. Phys. 28. L2118 (1989).

[3] S.J. Pearton, J.W. Lee and C. Yuan, Appl. Phys. Lett. 68, 2690 (1996).

[4] J. Neugebauer and C.G. Van de Walle, Phys. Rev. Lett. $\underline{75}$, 4452 (1995); Mat. Res. Soc. Symp. Proc. $\underline{423}, 619$ (1996); Mat. Res. Soc. Symp. Proc. $\underline{378}, 503$ (1995).

[5] J. Neugebauer and C.G. Van de Walle, Appl. Phys. Lett. $\underline{68}, 1829$ (1996).

[6] S.K. Estreicher and D.M. Maric, Mat. Res. Soc. Symp. Proc. 423, 613 (1996).

[7] M.S. Brandt, J.W. Ager, W. Gotz, N.M. Johnson, J.S. Harris, R.H. Molson and T.D. Moustakas, Phys. Rev. B포, 1478 (1994).

[8] J. Neugebauer and C.G. Van de Walle, Phys. Rev. B $\underline{50}, 8069$ (1994).

[9] S.J. Pearton, in GaN and Related Materials (Gordon and Breach, New York 1997).

[10] S. Nakamura, T. Mukai, M. Senoh and N. Iwasa, Jap. J. Appl. Phys. 31, L139 (1992).

[11] Y. Ohba and A. Hatano, Jap. J. Appl. Phys. $\underline{33}$, L1367 (1994).

[12] R.G. Wilson, S.J. Pearton, C.R. Abernathy and J.M. Zavada, J. Vac. Sci. Technol. A 13 , 719 (1995).

[13] S.J. Pearton, R.J. Shul, R.G. Wilson, F. Ren, J.M. Zavada, C.R. Abernathy, C. Vartuli, J. Lee, J. MacKenzie and J.R. Mileham, J. Electron. Mater. 25, 845 (1996).

[14] S.J. Pearton, C.R. Abernathy, J.D. MacKenzie, V. Hommerich, X. Wu, R.G. Wilson, R.N. Schwartz, J.M. Zavada and F. Ren, Appl. Phys. Lett. 71 , 1807 (1997).

[15] M.G. Weinsten, C.Y. Song, M. Stavola, S.J. Pearton, R.G. Wilson, R.J. Shul, K.P. Killeen and M.J. Ludowise, Appl. Phys. Lett. 72, 1703 (1998).

[16] C.G. Van de Walle, Phys. Rev. B $\underline{6}$, R10020 (1997). 
[17] S.J. Pearton, C.R. Abernathy, C.B. Vartuli, J.W. Lee, J.D. MacKenzie, R.G. Wilson, R.J. Shul, F. Ren and J.M. Zavada, J. Vac. Sci. Technol. A14, 831 (1996).

[18] S.J. Pearton, S. Bendi, K.S. Hones, V. Krishnamoorthy, R.G. Wilson, F. Ren, R.F. K Karlicek and R.A. Stall, Appl. Phys. Lett. $\underline{69}, 1879$ (1996).

[19] S.J. Pearton, C.R. Abernathy and F. Ren, Electron. Lett. 30, 527 (1994).

[20] J.W. Lee, S.J. Pearton, J.C. Zolper and R.A. Stall, Appl. Phys. Lett. 68, 2102 (1996).

[21] A. Burchard, M. Deicher, D. Forkel-Wirth, E.E. Haller, R. Magerle, A. Prospero and R. Stotzler, Mat. Res. Soc. Symp. $\underline{449}, 961$ (1997).

[22] S.C. Binari, H.B. Dietrich, G. Kelner, L.B. Rowland, K. Doverspike and D.K. Wickenden, J. Appl. Phys. $7 \underline{8}, 3008$ (1995).

[23] M.S. Brandt, N.M. Johnson, R.J. Molnar, R. Singh and T.D. Moustakas, Appl. Phys. Lett. 64, 2264 (1994).

[24] N.M. Johnson, W. Gotz, J. Neugebauer and C.G. Van de Walle, Mat. Res. Soc. Symp. Proc. $\underline{395}, 723$ (1996).

[25] M.A.L. Johnson, Z. Yu, C. Boney, W.C. Hughes, J.W. Cook, J.F. Schetzina, H. Zhao, B.J. Skromme and J.A. Edmond, Mat. Res. Soc. Symp. Proc. 449, 215 (1997).

[26] W. Gotz, N.M. Johnson, D.P. Bour, M.D. McCluskey and E.E. Haller, Appl. Phys. Lett. 69, 3725 (1996); W. Gotz, M.D. McCluskey, N.M. Johnson and D.P. Bour, Mat. Res. Soc. Symp. Proc. $\underline{468}, 117$ (1997). 


\section{FIGURE CAPTIONS}

Figure 1. Percentage of ${ }^{2} \mathrm{H}$ lost from $\mathrm{GaN}$ as a function of annealing temperature. The ${ }^{2} \mathrm{H}$ was incorporated either by direct implantation, or by plasma exposure which leads to deuterium in the bulk and surface regions of the $\mathrm{GaN}$.

Figure 2. SIMS profiles of ${ }^{2} \mathrm{H}$-implanted n-type (left) or p-type (right) $\mathrm{GaN}$, as a function of annealing temperatures.

Figure 3. Low temperature (5K) IR spectrum for $\mathrm{H}^{+}$-implanted $\mathrm{GaN}$ annealed at $400^{\circ} \mathrm{C}$. 


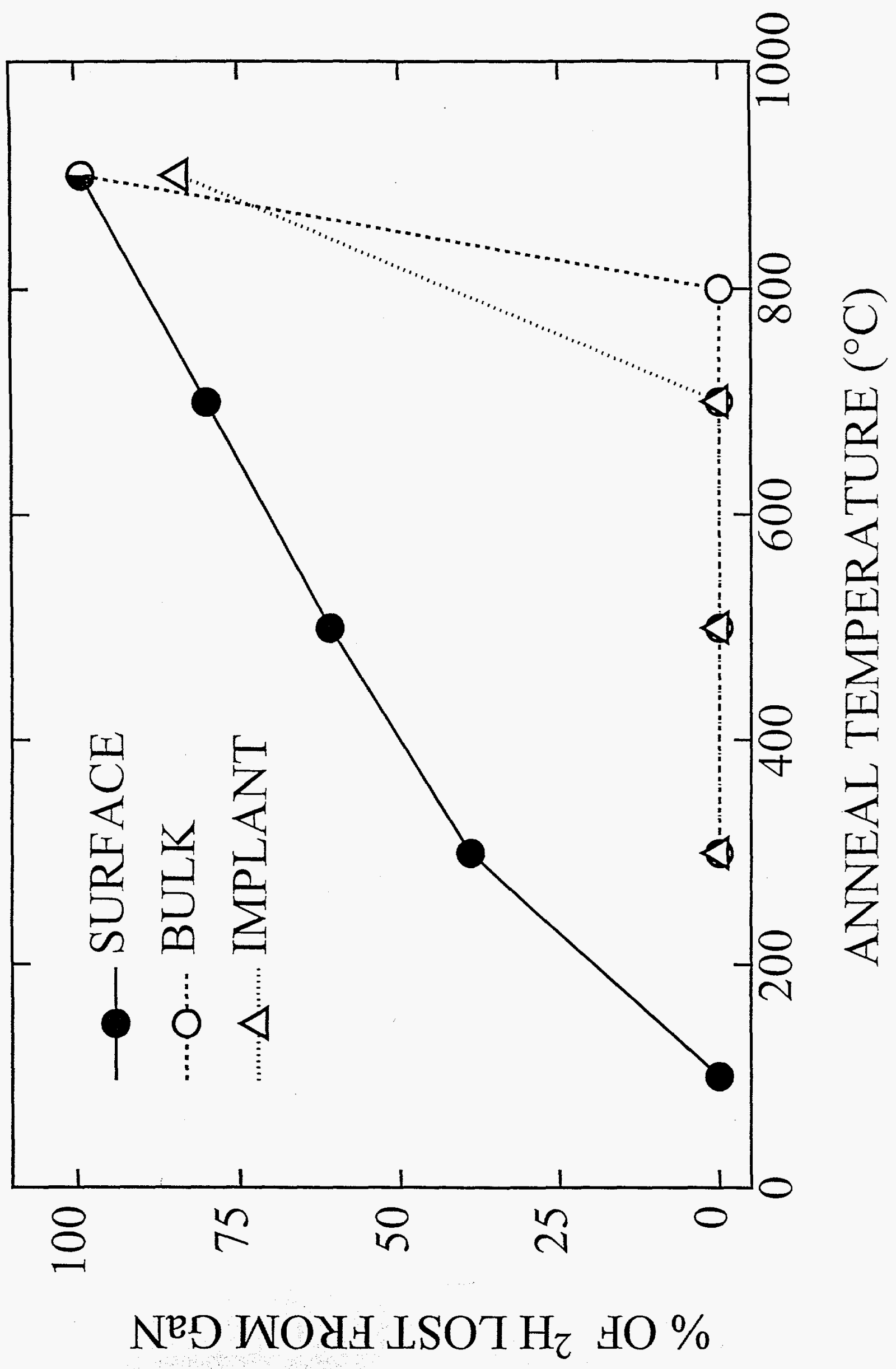


SECONDARY ION INTENSITY (cts/sec)
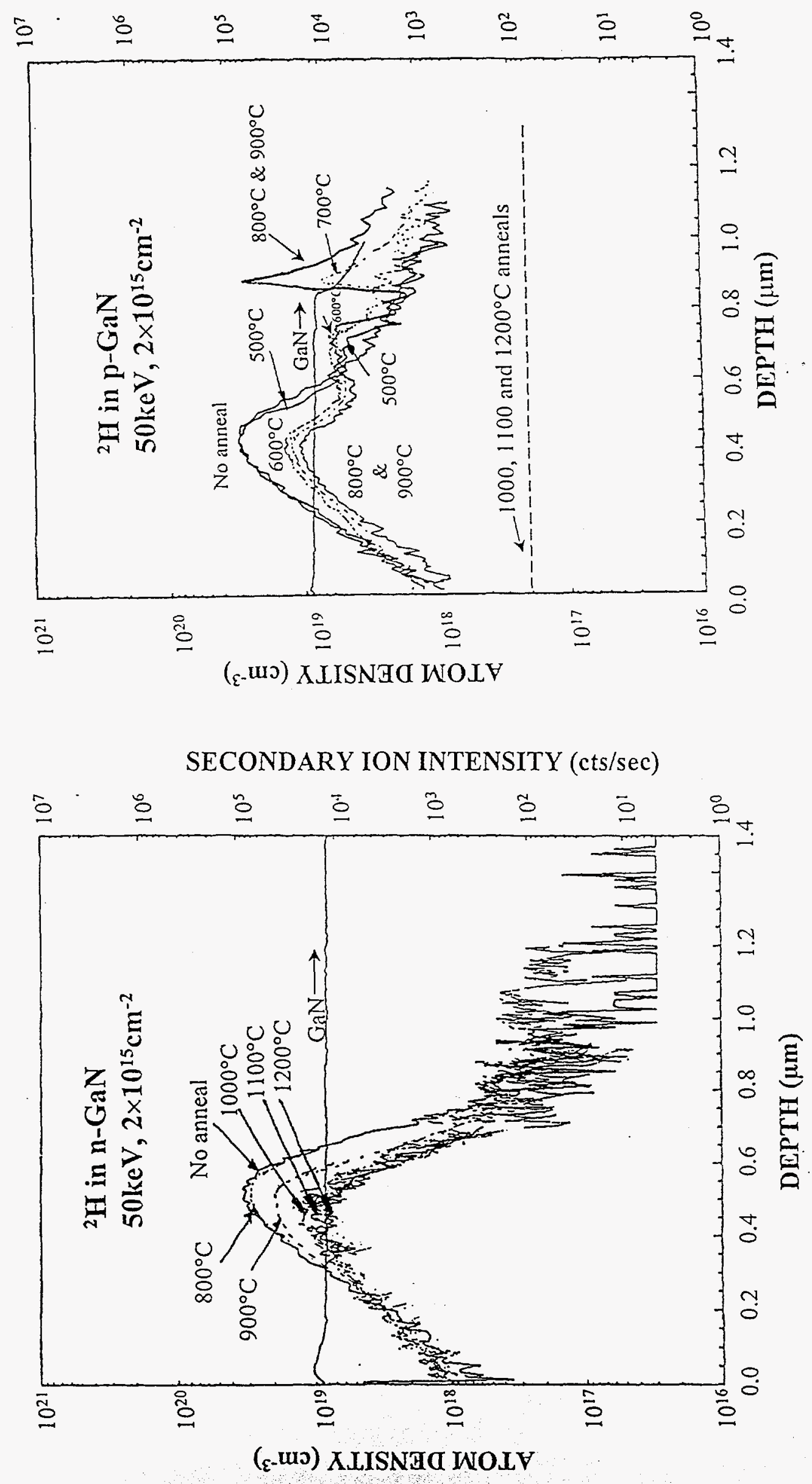


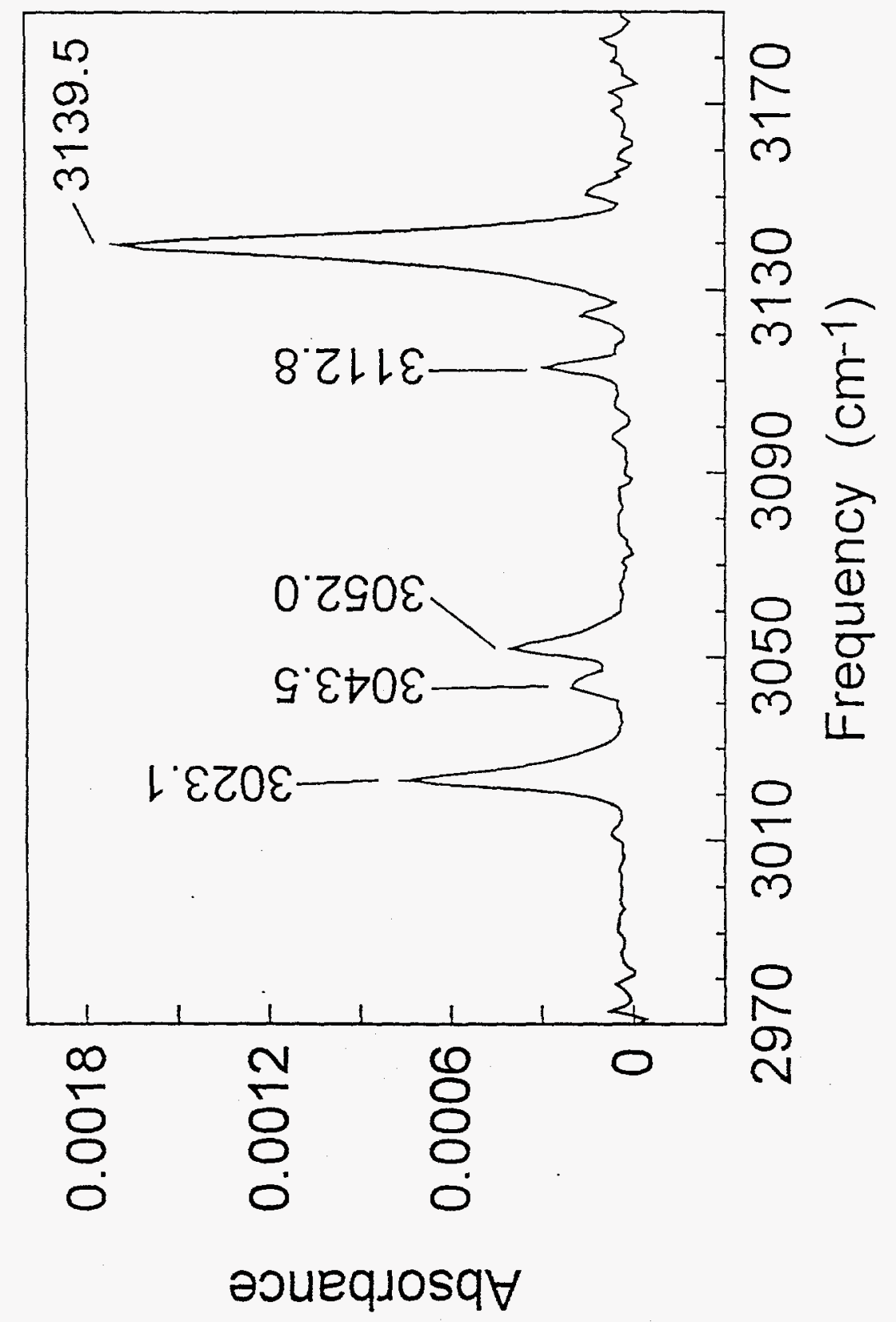

